\title{
Risk factors for bat contact and consumption behaviors in Thailand; a quantitative study
}

Kanokwan Suwannarong ${ }^{1}$, Sutin Chanabun², Phitsanuruk Kanthawee ${ }^{3}$, Santisith Khiewkhern ${ }^{4}$, Paisit Boonyakawee ${ }^{5}$, Kangsadal Suwannarong ${ }^{6}$, Chutarat Saengkul ${ }^{7}$, Nisachon Bubpa ${ }^{8}$ and Alongkorn Amonsin ${ }^{1,9^{*}}$ (D)

\begin{abstract}
Background: Bats serve as an important reservoir for emerging infectious diseases. Bat contact and consumption, which persists in Asia, poses risks for the transmission of bat-borne infections.

Methods: An analytical cross-sectional survey for risk factors associated with bat contact and consumption behaviors was conducted in ten provinces of Thailand from May 2016 to December 2017. A standardized questionnaire administered through face-to-face interviews was used to collect information from 626 villagers who lived in or nearby areas of high bat density. The questionnaire contained 23 independent variables related to sociodemographic, knowledge, attitudes, practices, and perceptions.

Results: The respondents $(n=626)$ were 285 females and 341 males, mean age of respondents was 47.58 years-old and lived in rural setting. Our results showed that $36.42 \%$ of respondents $\left(n_{1}=228\right)$ in 10 provinces reported bat contact during the past 6 months. Furthermore, $15.34 \%$ of respondents $\left(n_{2}=96\right)$ in 9 out of 10 provinces reported of having consumed bat meat in the past 6 months. Risk factors for bat contact included sex (male) $(\mathrm{OR}=1.56,95 \%$ $\mathrm{Cl} 1.09-2.28)$, educational attainment (lower than secondary school) $(\mathrm{OR}=1.45,95 \% \mathrm{Cl} 1.02-2.18)$, and the consideration of bats as being economically beneficial to the community $(\mathrm{OR}=3.18,95 \% \mathrm{Cl} 2.03-4.97)$, while agriculture-related occupation $(\mathrm{OR}=0.54,95 \% \mathrm{Cl} 0.37-0.79)$, knowledge that it is safe to eat bats $(\mathrm{OR}=0.58,95 \% \mathrm{Cl}$ 0.37-0.93), practice of allowing children to play with bats ( $\mathrm{OR}=0.65,95 \% \mathrm{Cl} 0.44-0.96)$, and attitude of feeling safe in areas where bats live $(\mathrm{OR}=0.56,95 \% \mathrm{Cl} 0.38-0.86)$ were statistically significant protective factors against bat contact. Risk factors for bat consumption included sex (male) $(\mathrm{OR}=2.48,95 \% \mathrm{Cl} 1.49-4.11)$ and educational attainment (lower than secondary school) $(\mathrm{OR}=2.21,95 \% \mathrm{Cl} 1.27-3.85)$, while knowledge of whether bats are safe to eat $(\mathrm{OR}=0.04,95 \% \mathrm{Cl} 0.01-0.25)$, knowledge of whether there are laws pertaining to hunting bats for consumption $(\mathrm{OR}=0.35,95 \% \mathrm{Cl} 0.18-0.71)$, and the practice of allowing children to play with bats $(\mathrm{OR}=0.51,95 \%$ Cl 0.31-0.81) were statistically significant protective factors against bat consumption.

(Continued on next page)
\end{abstract}

\footnotetext{
* Correspondence: alongkorn.a@chula.ac.th

${ }^{1}$ Center of Excellence for Emerging and Re-emerging Infectious Diseases in

Animals, Chulalongkorn University, Bangkok, Thailand

${ }^{9}$ Department of Veterinary Public Health, Faculty of Veterinary Science,

Chulalongkorn University, Bangkok 10330, Thailand

Full list of author information is available at the end of the article
}

(c) The Author(s). 2020 Open Access This article is licensed under a Creative Commons Attribution 4.0 International License, which permits use, sharing, adaptation, distribution and reproduction in any medium or format, as long as you give appropriate credit to the original author(s) and the source, provide a link to the Creative Commons licence, and indicate if changes were made. The images or other third party material in this article are included in the article's Creative Commons licence, unless indicated otherwise in a credit line to the material. If material is not included in the article's Creative Commons licence and your intended use is not permitted by statutory regulation or exceeds the permitted use, you will need to obtain permission directly from the copyright holder. To view a copy of this licence, visit http://creativecommons.org/licenses/by/4.0/ The Creative Commons Public Domain Dedication waiver (http://creativecommons.org/publicdomain/zero/1.0/) applies to the data made available in this article, unless otherwise stated in a credit line to the data. 


\begin{abstract}
(Continued from previous page)
Conclusions: This study provides a better understanding of the sociodemographic factors, knowledge, attitudes, perceptions and practices that might influence bat contact and bat consumption behaviors. Information on risk factors can be used for the development of appropriate education and communication interventions to promote proper knowledge, attitudes and practices regarding bats and bat-borne zoonotic diseases in Thailand and other areas in the Southeast Asia region with similar environmental and cultural characteristics.
\end{abstract}

Keywords: Bat, Behavior, Contact, Consumption, Risk factors, Thailand

\section{Background}

The human and wildlife interface has been a global concern in the past decade due to several zoonotic disease outbreaks related to wildlife contact. Pathogen transmission may occur through several routes, e.g., inhalation [1]; bites [2-4]; scratches [5]; hunting [6-9]; guano use as fertilizer [10]; food consumption [6, 11, 12]; handling, slaughtering and butchering; drinking water or food contaminated with saliva or feces [13]; and possible human-to-human transmission.

Bats are important reservoirs of several zoonotic pathogens. Bat-borne diseases in humans have been reported worldwide and have been considered global concerns; these include the Nipah virus [13, 14], the Hendra virus [15], Ebola [16], lyssaviruses [17], and severe acute respiratory syndrome coronavirus (SARS-CoV) $[2,18,19]$. It has been documented that several factors influence human contact with bats. For example, previous studies in Asia, and North America reported that sex [6], occupation [4], and locations of bat habitats [6] influence human-bat interactions. Bats play a cultural role in Thailand including medicinal, religious, and culinary [10]. A better understanding of human-bat interactions is critical to understanding zoonotic disease spillover and has been insufficiently studied [20]. Especially in Thailand, the understanding of human-bat interactions and the epidemiological links involved in bat-borne disease and bat consumption is still insufficient.

The objective of this study was to determine the factors associated with bat contact and bat consumption behaviors in ten provinces of Thailand from May 2016 to December 2017. Our results will support the development of appropriate education and communication interventions to promote proper knowledge, attitudes and practices regarding bats and bat-borne zoonotic diseases in Thailand and Southeast Asia.

\section{Methods}

\section{Study design}

An analytical cross-sectional study was conducted to identify the factors associated with bat contact and bat consumption behaviors among persons who lived in or near areas of high bat density within at least 6 months before the study. The questionnaire interviews were conducted from May 2016 to July 2017. The Chulalongkorn
University Institution Review Boards (IRBs) and Chiang Rai provincial health office approved the human study (Ref No. 034/59 and 26/ 2559). This study obtained agreements from local administrative offices and the chiefs of villages to conduct data collection at the study sites. Written informed consent forms were signed by the participants after they received information about the objectives of the study and prior to the interviews.

\section{Study sites and study population selection}

Different sampling methods were applied to select the study sites and study populations. The whole country was first stratified into four regions; central, northern, northeastern and southern Thailand. Provinces, districts and villages in each region were then purposively selected based on; 1) a high density of bats in the villages/ study areas, 2) a potential bat-human interface was observed by researchers during scoping visits, discussed with some villagers and/or local authorities, and 3) information obtained from the relevant local and national authorities such as the Ministry of Natural Resources and Environment (MNRE), and the Ministry of Public Health $(\mathrm{MoPH})$. Lastly, a simple random sampling method (SRS) was used to select respondents from official household registry records that were obtained from the local health promotional hospitals in the villages.

In this study, 10 provinces were selected as representatives of regions in Thailand that have different living characteristics and practices. The provinces were Ang Thong, Ayutthaya, Lopburi and Saraburi (central provinces); Chiang Mai and Chiang Rai (northern provinces); KhonKaen and UbonRatchathani (northeastern provinces); and Krabi and Surat Thani (southern provinces) (Fig. 1 and Table 1). Bats from each study site were collected for species identification using physical characteristics and DNA sequence variations in mitochondrial cytochrome-b (CytB) [21].

\section{Sample size estimation, respondents, and recruitment procedures}

The inclusion criteria for respondents were males or females between 20 and 75 years of age who had lived in the selected areas for at least 6 months before data 


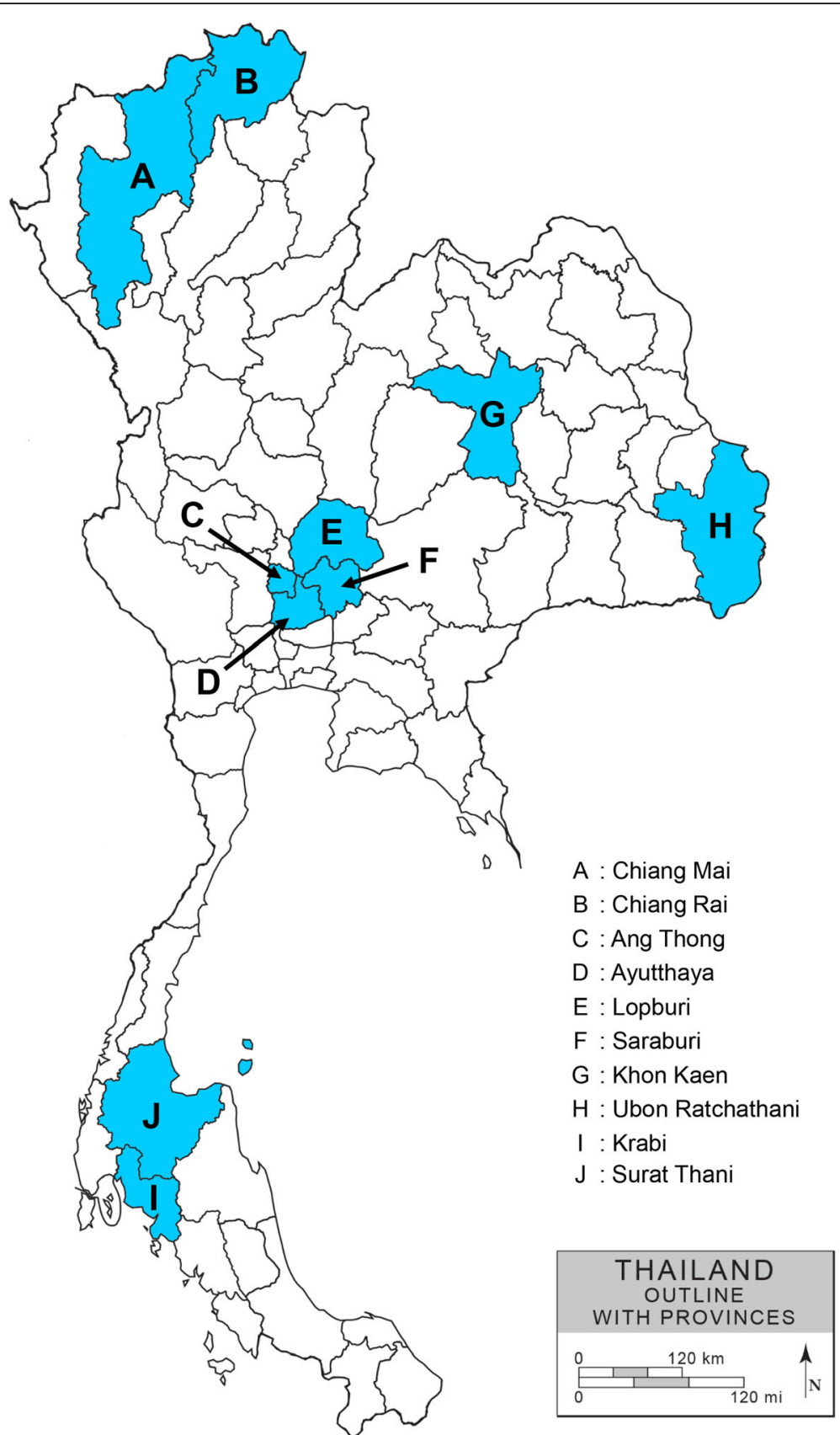

Fig. 1 Maps of provinces and study sites in Thailand (Thailand map is purchased with permission of@ Copyright 2007 by World Trade Press. All Rights Reserved)

collection and were willing to participate in this study. The sample size calculation for this study was as follows:

$$
\mathrm{n}=\frac{\left[Z^{2}(1-\alpha / 2) p(1-p)\right]}{\mathrm{d}^{2}}
$$

Here, $p=$ proportion of participants with bat contact. Based on a previous study, $23.00 \%$ of respondents reported bat consumption at some time in their lives [22].
The variable $\mathrm{p}$ is 0.23 for this calculation, $\mathrm{z}=1.96$ (95\% confidence interval), and $d$ (margin of error) $=5 \%$. Therefore, the calculated sample size was 340 . To increase the power, the sample size was elevated to 626 .

Simple random sampling (SRS) was used on the lists of the respondents retrieved from health promotional hospitals in the study areas. After SRS of respondents was conducted, the participants were contacted by trained researchers for data collection. Using a standardized 
Table 1 Numbers of districts, villages, respondents $(N=626)$, numbers of respondents who reported bat contact $(n=228)$, and number of respondents who reported bat consumption $(n=96)$

\begin{tabular}{|c|c|c|c|c|c|c|}
\hline \multirow[b]{2}{*}{ Regions } & \multirow[b]{2}{*}{ Provinces } & \multirow[b]{2}{*}{ No. of districts } & \multirow[b]{2}{*}{ No. of villages } & \multicolumn{3}{|c|}{ No. of respondents (\%) } \\
\hline & & & & No. of respondents & Reported bat contact & Reported bat consumption \\
\hline Northern & Chiang Mai & 1 & 4 & $80(12.78 \%)$ & $28(12.28 \%)$ & $27(28.13 \%)$ \\
\hline Northern & Chiang Rai & 1 & 2 & $60(9.58 \%)$ & $20(8.77 \%)$ & $13(13.54 \%)$ \\
\hline Central & Ang Thong & 1 & 1 & $64(10.22 \%)$ & $26(11.40 \%)$ & $0(0.00 \%)$ \\
\hline Central & Ayutthaya & 1 & 1 & $60(9.58 \%)$ & $24(10.53 \%)$ & $1(1.04 \%)$ \\
\hline Central & Lopburi & 3 & 4 & 77 (33.77\%) & 25 (10.96\%) & $1(1.04 \%)$ \\
\hline Central & Saraburi & 1 & 1 & $42(6.71 \%)$ & $21(9.21 \%)$ & $3(3.13 \%)$ \\
\hline Northeastern & Khon Kaen & 4 & 8 & 69 (11.02\%) & $21(9.21 \%)$ & $3(3.13 \%)$ \\
\hline Northeastern & Ubon Ratchathani & 1 & 1 & $60(9.58 \%)$ & $24(10.53 \%)$ & $18(18.75 \%)$ \\
\hline Southern & Krabi & 1 & 2 & $60(9.58 \%)$ & 19 (8.33\%) & $14(14.58 \%)$ \\
\hline \multirow[t]{2}{*}{ Southern } & Surat Thani & 5 & 13 & $54(8.63 \%)$ & $20(8.77 \%)$ & $16(16.67 \%)$ \\
\hline & & 19 & 37 & $626(100 \%)$ & $228(100 \%)$ & 96 (100\%) \\
\hline
\end{tabular}

questionnaire, a face-to-face interview was conducted with the respondents in a place that was not too secluded but still free from disturbances.

\section{A standardized questionnaire}

A questionnaire was designed to collect information on bat contact and bat consumption behaviors. This questionnaire was modified from previous reports [10, 23, 24]. The questionnaire interview was administered to collect information on sociodemographic factors, knowledge, attitudes, practices and perceptions for bat contact and bat consumption behaviors. The questionnaire was pretested with 30 respondents in a district with the same environmental and population characteristics as the actual selected sites. The questionnaire was refined per the pretest results. Field researchers were trained in its administration and in conducting questionnaire interviews with written informed consent forms obtained prior to the interviews. After the interviews, the information was checked for validity and precision before it was entered into SPSS Software Version 22 (Chicago, IL).

\section{Study variables for risk factors for bat contact and bat consumption behaviors}

Independent variables $(n=23)$ were included in the analysis. The variables were based on previous relevant studies [10, 25-29]. The independent variables, including the sociodemographic information, knowledge, attitudes, practices, and perceptions were as follows:

a) Sociodemographic information (10 variables)

- Sex (male vs female)

- Age group (> age of 36 years vs $\leq 36$ years)

- Occupation (farmer vs other)
- Marital status (married and cohabiting vs single)

- Family size ( $\geq 2$ people vs $<2$ people)

- Family monthly income $(\leq 15,000$ Baht vs $>15,000)$

- Own a car (yes vs no)

- Own a motorcycle (yes vs no)

- Number of children (none vs $\geq 1$ child)

- Education attainment ( $\leq$ secondary school vs other)

b) Knowledge, attitudes, practices and perceptions (13 variables)

- Humans can get diseases from bats (true vs false)

- There are no concerns about getting diseases from bats (true vs false)

- Bats can transmit diseases to humans (true vs false)

- Bats are economically beneficial to the community (agree vs disagree)

- One can contract diseases if exposed to bats (true vs false)

- One can contract diseases by drinking water from the same places as bats (true vs false)

- One can contract diseases by eating fruits left by bats (true vs false)

- Bat guano is safe to use (true vs false)

- It is safe to eat bats (true vs false)

- There are laws related to hunting bats for consumption (true vs false)

- Children are allowed to play with bats (true vs false)

- Dead bats that are found are brought home for food (true vs false)

- One feels safe in areas where bats live (true vs false)

The dependent variable was a report of either one of bat contact experiences by the study respondents. List of bat contact experiences included the following: 
- Found dead bat(s) in house

- Found live bat(s) in house, the community or tourist location

- Cleaned bat guano from house or the community

- Cleaned bat carcasses from house or the community

- Bat guano mining/collecting

- Use of bat guano

- Bitten by a bat

- Consumed bats for food

- Other activities, e.g., hunted bats, exposed to urine of bats

\section{Analysis of risk factors for bat contact and bat consumption behaviors}

The interviewed data were entered into and analyzed by SPSS software version 22 (Chicago, IL). After data cleaning, the dependent and independent variables were assessed. Data were analyzed in 2 steps. First, bivariate analysis was performed, in which the degree of association of each variable was computed and each of the independent variables was analyzed separately. Second, a stepwise logistic regression model was constructed including independent variables that had $p$ values $\leq 0.15$ results in bivariate analysis. This second step used $p \leq$ 0.05 as the cutoff point for identifying statistically significant variables.

\section{Results}

\section{Sociodemographic information of respondents}

In this study, 626 respondents participated in the questionnaire interview. These respondents from 37 villages of 16 districts in 10 provinces in Thailand (Fig. 1 and Table 1). Bats species from each study site were identified: Chiang Mai (Scotophilus heathii and Megaderma spasma), Chiangxs Rai (Taphozous melanopogon), Lopburi (Taphozous melanopogon and Chaerephon plicatus), Khon Kaen (Chaerephon plicatus), and Ayutthaya, Ang Thong, Saraburi (Pteropus lylei). Of the 626 respondents who participated in the questionnaire interview, 228 (36.42\%) respondents from 10 provinces reported having experienced bat contact during the past 6 months before data collection. Moreover, 96 (15.34\%) respondents in 9 out of 10 provinces reported having consuming bat meat in the past 6 months.

The 626 respondents were 285 females and 341 males. The mean age of the respondents was 47.58 years. Approximately $21.09 \%$ of respondents were aged $>36$ years. Most of them lived in rural settings $(93.29 \%)$ and were married or cohabiting (84.03\%). Respondents worked as farmers (rice, grains or vegetables) (35.78\%), followed by temporary employees (22.68\%), government officers (10.54\%), housewives (7.03\%), and shop vendors/owners (5.59\%). Most of the respondents (65.65\%) had attained educational levels lower than secondary school, and $80.35 \%$ had families composed of more than 2 persons.
Most respondents had a monthly family income of $\leq 15$, 000 Baht (500 USD) (69.97\%). Most respondents owned a motorcycle (91.69\%), while fewer owned a car (50.16\%).

\section{Bat contact experiences among respondents}

In this study, 228 respondents in 10 provinces reported a bat contact experience during the past 6 months before data collection. Among those 228 respondents, 56.14\% reported encountering live bats in a house, the community or a tourist location, while $42.10 \%$ reported eating bats for food, $34.21 \%$ found bat guano in a house or the community, $28.51 \%$ found dead bats in the house, $20.18 \%$ participated in bat guano mining/collecting, $19.74 \%$ cleaned bat carcasses from a house or the community, $10.96 \%$ used bat guano as fertilizer, $17.98 \%$ were involved in other contact activities (e.g., took bats from nets), and $7.02 \%$ been bitten by a bat in the past 6 months (Table 2).

\section{Knowledge, attitudes, practices and perceptions regarding bat contact experiences}

In this study, the questionnaire interview contained 10 sociodemographic questions and 13 questions related to the knowledge, attitudes, practices and perceptions regarding bat contact experiences. Bivariate analysis was performed to determine the associations between bat contact experiences and twenty-three independent variables. Of the 23 independent variables, 11 variables had significantly associations in the bivariate analysis, using $p \leq 0.15$ as a cutoff point: sex (male), age group ( $>36$ years), occupation (agriculture-related occupation), educational attainment ( $\leq$ secondary school), family monthly income $(<15,000 \mathrm{Baht})$, no concerns about getting diseases from bats, considered bats to be economically beneficial to the community, believed it is safe to eat bats, allowed children to play with bats, and felt safe in areas where bats live (Table 3). All 11 variables were included in the stepwise logistic regression analysis for bat contact experiences. The results showed that sex (male) $(\mathrm{OR}=1.56,95 \% \mathrm{CI} 1.09-2.28, p=0.014)$, educational attainment $(\leq$ secondary school) $(\mathrm{OR}=1.45,95 \%$ CI $1.02-$ 2.18, $p=0.041$ ), and considered bats to be economically beneficial to the community (OR $=3.18$, 95\% CI $2.03-$ 4.97, $p<0.001)$ were statistically significant associated with bat contact experiences, while occupation (agriculture-related occupation) $(\mathrm{OR}=0.54,95 \%$ CI $0.37-0.79$, $p=0.002)$, believed it is safe to eat bats ( $\mathrm{OR}=0.58,95 \%$ CI $0.37-0.93, p=0.023$ ), allowed children to play with bats $(\mathrm{OR}=0.65,95 \% \mathrm{CI} 0.44-0.96, p=0.031)$, and felt safe in areas where bats live $(\mathrm{OR}=0.56,95 \%$ CI 0.38 $0.86, p=0.007$ ) were statistically significant protective factors against bat contact experiences (Table 4). 
Table 2 Details of bat contact experiences among 228 respondents who reported bat contact experiences (dependent variables)

\begin{tabular}{ll}
\hline Bat contact experience & No. of respondents who reported bat contact (\%) \\
\hline Found dead bat(s) in house & $65(28.51)$ \\
Found live bat(s) in house, community or tourist location & $128(56.14)$ \\
Cleaned bat guano from house or the community & $78(34.21)$ \\
Cleaned bat carcasses from house or the community & $45(19.74)$ \\
Bat guano mining/ collecting & $46(20.18)$ \\
Used bat guano & $25(10.96)$ \\
Been bitten by a bat & $16(7.02)$ \\
Consumed bats for food & $96(42.10)$ \\
Other activities e.g. hunted bat(s), exposed to urine of bat(s) & $41(17.98)$ \\
\hline
\end{tabular}

${ }^{a}$ multiple responses

\section{Bat consumption behaviors among respondents}

Among the 626 respondents, 96 respondents (15.34\%; 28 females and 68 males) reported eating bats in the past 6 months. Of the respondents who reported contacts with bats, $42.10 \%(96 / 228)$ reported eating bats in the past 6 months. They also reported that bats were hunted, butchered, slaughtered, and cooked by several categories of persons (e.g., husbands, wives, neighbors, children, or hunters) in their communities. In this study, 170 out of 626 respondents $(27.16 \%)$ reported having eaten bats in their lifetime, of whom $62.35 \%$ (106/170) reported consuming bats more than 10 years ago, $11.18 \%(19 / 170)$ who reported eating bats during the last 1-10 years, $20.00 \%(34 / 170)$ who reported eating bats within the past 12 months, $2.94 \%$ (5/ 170) who reported eating bats in the past month, $2.35 \%(4 / 170)$ who reported eating bats within week of data collection, and $1.18 \%(2 / 170)$ who reported eating bats within the preceding week.

Of the 96 respondents who reported eating bats, $70.83 \%$ were male and $83.33 \%$ were $\leq 36$ years old (mean age of respondents 47.21 years old). Most respondents were married or cohabiting (85.42\%) and had more than one child (69.79\%). The occupations of respondents were farmers (rice, grains or vegetables) (39.58\%), followed by temporary employees (29.17\%). Most respondents had attained an educational level $\leq$ secondary school (79.17\%) and had families composed of more than 2 persons (76.04\%). Most of the respondents (66.67\%) had monthly family income $\leq 15,000$ Baht (500 USD). Some respondents owned a car (42.71\%), majority owned a motorcycle (96.88\%). Of the 96 respondents, those in the northern region, Chiang Mai $(28.13 \%)$ and Chiang Rai (13.54\%), reported more bat consumption than those in other provinces, including those in the northeastern region, Ubon Ratchathani (18.75\%), southern region, Surat Thani (16.67\%) and Krabi (14.58\%). On the other hand, respondents in the central region reported less bat consumption (Table 1).
With regard to the details of bat consumption behaviors, we found that $26.04 \%(25 / 96)$ of respondents reported killing bats themselves, followed by vendors (15.63\%), hunters (13.54\%), and neighbors (11.56\%). The participants reported that no children aged $0-10$ years old killed bats. With respect to preparing and cooking bats for food, 34.38\% (33/96) of respondents prepared bat meat by themselves, followed by spouses (14.58\%), neighbors (11.56\%), and children (1.04\%). Persons reported that the bats were eaten by spouses (48.96\%), neighbors (39.58\%), and children (13.54\%). Most respondents reported eating cooked bat meat (98.96\%, 95/96), while only one respondent, a 63-year-old female from Chiang Rai province, reported eating raw bat meat. Bats were obtained by hunting in caves (30.21\%), purchasing from local markets (19.79\%), hunting by themselves (13.54\%), and hunting by neighbors (8.33\%). Dishes containing bat were "Kang Om" (spicy vegetable soup) (18.75\%), followed by spicy stir fry (13.54\%), "Kua Kling" (dry spicy fry with herbs), and deep-fried bat meat $(8.33 \%)$. The preferred recipes varied among provinces or regions; for example, people in the northern region, Chiang Mai, preferred to cook "Kang Om" while those in southern provinces, Krabi, preferred spicy stir fry to other dishes. The field investigation showed that a typical bat preparation process included butchering the bats, selecting the parts for consumption, adding additional herbs for flavor, and boiling the ingredients in a large pot (Fig. 2).

\section{Knowledge, attitudes, practices and perceptions regarding bat consumption behaviors}

In this study, 23 variables (sociodemographic factors, knowledge, attitudes, practices and perceptions) were involved in the bivariate analysis, and eleven independent variables were eligible for the stepwise logistic regression analysis. These included sociodemographic variables (sex, educational attainment, owning a car, and owning a 
Table 3 Bivariate analysis of bat contact experiences (Counts $\left(n_{1}=228\right)$, odds ratios, confidence intervals and $p$-values of independent variables)

\begin{tabular}{|c|c|c|c|c|c|c|}
\hline \multirow[t]{2}{*}{ Variables } & \multirow{2}{*}{$\begin{array}{l}\text { Total } \\
\text { number } \\
(N= \\
626)\end{array}$} & \multicolumn{2}{|c|}{$\begin{array}{l}\text { Reported bat contact } \\
(n=228)\end{array}$} & \multirow[t]{2}{*}{$\begin{array}{l}\text { Unadjusted } \\
\text { odds ratio }\end{array}$} & \multirow[t]{2}{*}{$95 \% \mathrm{Cl}$} & \multirow[t]{2}{*}{$P$-value } \\
\hline & & $\mathrm{n}$ & $\%$ & & & \\
\hline \multicolumn{7}{|l|}{ Sociodemographic information } \\
\hline \multicolumn{7}{|l|}{ 1. Sex } \\
\hline Male & 341 & 141 & 61.84 & 0.62 & $0.45-0.87$ & $0.005^{*}$ \\
\hline Female & 285 & 87 & 38.16 & 1 & & \\
\hline \multicolumn{7}{|l|}{ 2. Age group } \\
\hline$>36$ years & 132 & 41 & 17.98 & 1.35 & $0.89-2.04$ & $0.150^{*}$ \\
\hline$\leq 36$ years & 494 & 187 & 82.02 & 1 & & \\
\hline \multicolumn{7}{|l|}{ 3. Occupation } \\
\hline Agriculture-related occupation & 224 & 66 & 28.95 & 1.62 & $1.14-2.29$ & $0.007^{*}$ \\
\hline Other & 402 & 162 & 71.05 & 1 & & \\
\hline \multicolumn{7}{|l|}{ 4. Marital status } \\
\hline Married or cohabiting & 526 & 188 & 82.46 & 1.20 & $0.77-1.86$ & 0.417 \\
\hline Single & 100 & 40 & 17.54 & 1 & & \\
\hline \multicolumn{7}{|l|}{ 5. Family size } \\
\hline$\leq 2$ people & 123 & 40 & 17.54 & 1.24 & $0.82-1.88$ & 0.316 \\
\hline$>2$ people & 503 & 188 & 82.46 & 1 & & \\
\hline \multicolumn{7}{|l|}{ 6. Number of children } \\
\hline O children & 195 & 74 & 32.46 & 0.91 & $0.64-1.29$ & 0.593 \\
\hline$\geq 1$ children & 431 & 154 & 67.54 & 1 & & \\
\hline \multicolumn{7}{|l|}{ 7. Educational attainment } \\
\hline$\leq$ Secondary school & 411 & 159 & 69.74 & 0.75 & $0.53-1.06$ & $0.104^{*}$ \\
\hline Other & 215 & 69 & 30.26 & 1 & & \\
\hline \multicolumn{7}{|l|}{ 8. Family monthly income } \\
\hline$\leq 15,000$ Baht & 438 & 150 & 65.79 & 1.36 & $0.96-1.94$ & $0.084^{*}$ \\
\hline$>15,000$ Baht & 188 & 78 & 34.21 & 1 & & \\
\hline \multicolumn{7}{|l|}{ 9. Own a car } \\
\hline Yes & 314 & 110 & 48.25 & 1.13 & $0.81-1.56$ & 0.468 \\
\hline No & 312 & 118 & 51.75 & 1 & & \\
\hline \multicolumn{7}{|l|}{ 10. Own a motorcycle } \\
\hline Yes & 574 & 210 & 92.11 & 0.92 & $0.51-1.67$ & 0.777 \\
\hline No & 52 & 18 & 7.89 & 1 & & \\
\hline \multicolumn{7}{|c|}{ Knowledge, attitudes, practices and perceptions } \\
\hline \multicolumn{7}{|c|}{ 11. Human can get diseases from bats } \\
\hline True & 40 & 15 & 6.58 & 0.95 & $0.49-1.85$ & 0.884 \\
\hline False & 586 & 213 & 93.42 & 1 & & \\
\hline \multicolumn{7}{|c|}{ 12. There are no concerns about getting diseases from bats } \\
\hline True & 48 & 24 & 10.53 & 0.64 & $0.43-0.95$ & $0.026^{*}$ \\
\hline False & 578 & 204 & 89.47 & 1 & & \\
\hline \multicolumn{7}{|c|}{ 13. Bats can transmit diseases to humans } \\
\hline True & 84 & 28 & 12.28 & 1.17 & $0.72-1.90$ & 0.527 \\
\hline False & 542 & 200 & 87.72 & & & \\
\hline
\end{tabular}


Table 3 Bivariate analysis of bat contact experiences (Counts $\left(n_{1}=228\right)$, odds ratios, confidence intervals and $p$-values of independent variables) (Continued)

\begin{tabular}{|c|c|c|c|c|c|c|}
\hline \multirow[t]{2}{*}{ Variables } & \multirow{2}{*}{$\begin{array}{l}\text { Total } \\
\text { number } \\
(N= \\
626)\end{array}$} & \multicolumn{2}{|c|}{$\begin{array}{l}\text { Reported bat contact } \\
(n=228)\end{array}$} & \multirow[t]{2}{*}{$\begin{array}{l}\text { Unadjusted } \\
\text { odds ratio }\end{array}$} & \multirow[t]{2}{*}{$95 \% \mathrm{Cl}$} & \multirow[t]{2}{*}{$P$-value } \\
\hline & & $\mathrm{n}$ & $\%$ & & & \\
\hline \multicolumn{7}{|c|}{ 14. Bats are economically beneficial to the community } \\
\hline Agree & 108 & 65 & 28.51 & 0.30 & $0.20-0.47$ & $<0.001^{*}$ \\
\hline Disagree & 518 & 163 & 71.49 & 1 & & \\
\hline \multicolumn{7}{|c|}{ 15. One can contract diseases if exposed to bats } \\
\hline True & 101 & 37 & 16.63 & 0.99 & $0.64-1.54$ & 0.961 \\
\hline False & 525 & 191 & 83.77 & 1 & & \\
\hline \multicolumn{7}{|c|}{ 16. One can contract diseases by drinking water from the same place as bats do } \\
\hline True & 139 & 48 & 21.05 & 1.11 & $0.75-1.65$ & 0.600 \\
\hline False & 487 & 180 & 78.77 & 1 & & \\
\hline \multicolumn{7}{|c|}{ 17. One can contract diseases by eating fruit left by bats } \\
\hline True & 170 & 64 & 28.07 & 0.93 & $0.65-1.14$ & 0.697 \\
\hline False & 456 & 164 & 71.93 & 1 & & \\
\hline \multicolumn{7}{|c|}{ 18. Bat guano is safe to use } \\
\hline True & 58 & 14 & 6,14 & 1.90 & $1.02-3.55$ & $0.041^{*}$ \\
\hline False & 568 & 214 & 93.86 & & & \\
\hline \multicolumn{7}{|c|}{ 19. Bats are safe to eat } \\
\hline True & 169 & 37 & 16.23 & 2.56 & $1.70-3.86$ & $<0.001^{*}$ \\
\hline False & 457 & 191 & 83.77 & & & \\
\hline \multicolumn{7}{|c|}{ 20. There are laws related to hunting bats for consumption } \\
\hline True & 196 & 66 & 28.95 & 1.19 & $0.84-1.70$ & 0.335 \\
\hline False & 430 & 162 & 71.05 & 1 & & \\
\hline \multicolumn{7}{|c|}{ 21. Children are allowed to play with bats } \\
\hline True & 431 & 138 & 60.53 & 1.82 & $1.29-2.57$ & $0.001^{*}$ \\
\hline False & 195 & 90 & 39.47 & 1 & & \\
\hline \multicolumn{7}{|c|}{ 22. Found dead bat(s) and brought home for food } \\
\hline True & 518 & 195 & 85.53 & 0.73 & $0.47-1.14$ & 0.164 \\
\hline False & 108 & 33 & 14.47 & 1 & & \\
\hline \multicolumn{7}{|c|}{ 23. Feel safe in areas where bats live } \\
\hline True & 210 & 47 & 20.61 & 2.67 & $1.83-3.90$ & $<0.001^{*}$ \\
\hline False & 416 & 181 & 79.39 & 1 & & \\
\hline
\end{tabular}

${ }^{*}$ Cut-off point for stepwise logistic regression at $p<0.15$

motorcycle) and variables pertaining to knowledge, attitudes, practices and perceptions (knowledge of one can contract diseases by drinking water from the places where bats live, knowledge of whether it is safe to eat bats, knowledge of whether there are laws pertaining to hunting bats for consumption, practice of allowing their children to play with bats, and attitude of feeling safe in areas where bats live) (Table 5). In the stepwise multiple logistic regression analysis, 5 independent variables were statistically significant $(p \leq 0.5)$. Sex (male) (OR $=2.48$, 95\% CI 1.49 4.11, $p<0.001)$ and educational attainment ( $\leq$ secondary school) $(\mathrm{OR}=2.21,95 \%$ CI 1.27-3.85, $p=0.005)$ were statistically significant related to bat consumption behaviors, while knowledge of whether bats are safe to eat (OR $=0.04,95 \%$ CI $0.01-0.25, p=0.001)$, knowledge of whether there are laws related to hunting bats for consumption $(\mathrm{OR}=0.35,95 \% \mathrm{CI} 0.18-0.71, p=0.004)$, and allowing children to play with bats $(\mathrm{OR}=0.51,95 \% \mathrm{CI}$ $0.31-0.81, p=0.006$ ) were statistically significant protective factors against bat consumption behaviors (Table 6).

\section{Discussion}

This is the first quantitative study regarding the risk factors for bat contact and bat consumption behaviors in 
Table 4 Stepwise logistic regression analysis of bat contact experiences (Coefficient, odds ratios, confidence intervals and $p$-values of independent variables)

\begin{tabular}{|c|c|c|c|c|}
\hline Variables & Coefficient & Odds ratio & $95 \% \mathrm{Cl}$ & $P$-value \\
\hline \multicolumn{5}{|l|}{ Sociodemographic information } \\
\hline Sex (male) & 0.45 & 1.56 & $1.09-2.28$ & $0.014^{*}$ \\
\hline Occupation (agriculture-related occupation) & -0.61 & 0.54 & $0.37-0.79$ & $0.002^{*}$ \\
\hline Educational attainment ( $\leq$ secondary school level) & 0.39 & 1.45 & $1.02-2.18$ & $0.041^{*}$ \\
\hline \multicolumn{5}{|l|}{ Knowledge, attitudes, practices and perceptions } \\
\hline Considered bat(s) to be economically beneficial to the community (agreed) & 1.16 & 3.18 & $2.03-4.97$ & $<0.001^{*}$ \\
\hline Bat are safe to eat (true) & -0.54 & 0.58 & $0.37-0.93$ & $0.023^{*}$ \\
\hline Children are allowed to play with bats (true) & -0.43 & 0.65 & $0.44-0.96$ & $0.031^{*}$ \\
\hline Felt safe in areas where bats live (true) & -0.58 & 0.56 & $0.38-0.86$ & $0.007^{*}$ \\
\hline
\end{tabular}

*Statistically significant at $p<0.05$
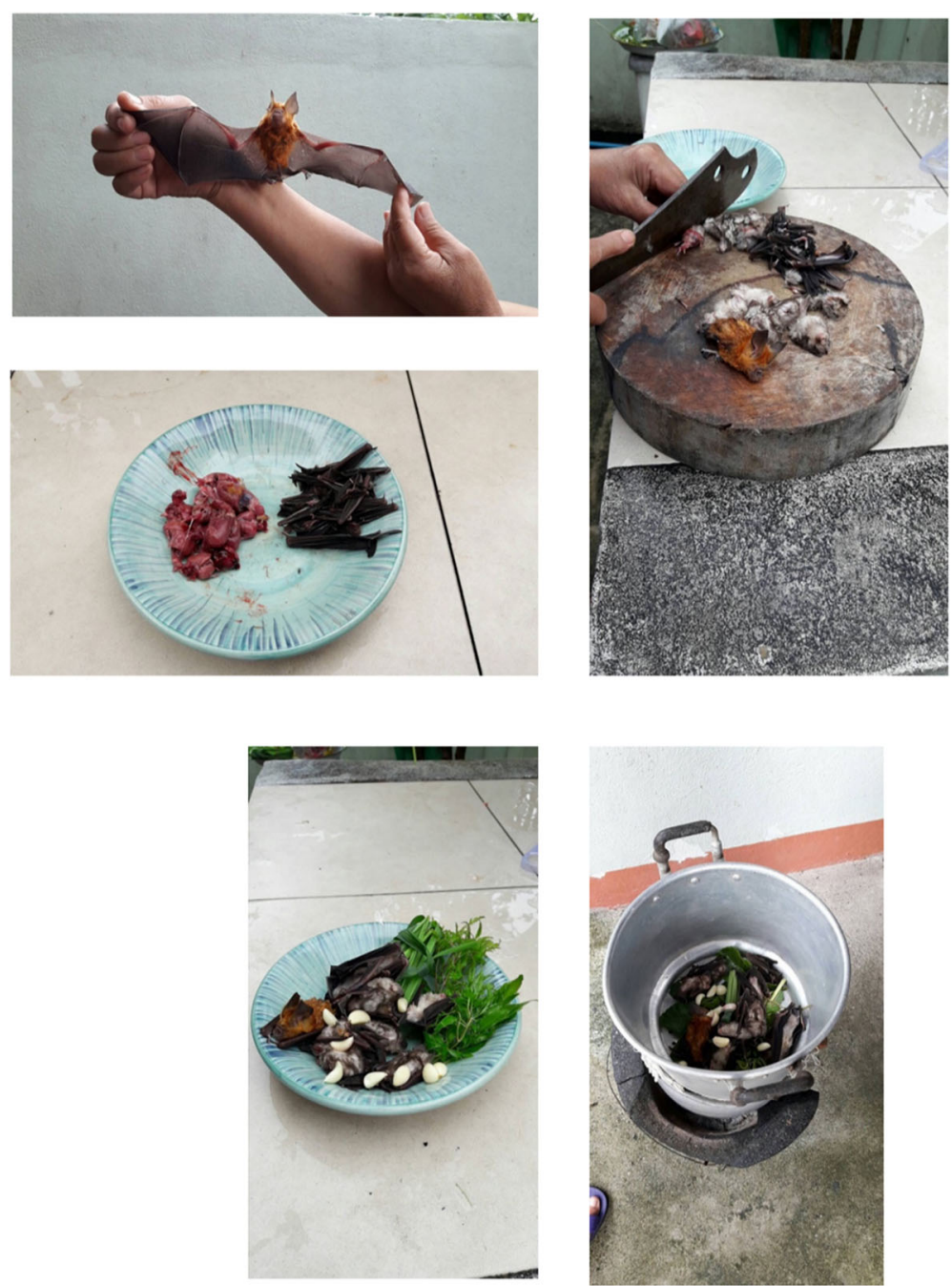

Fig. 2 Local food preparation of bat meats (the authors declared the ownership of pictures) 
Table 5 Bivariate analysis of bat consumption behavior (Counts $\left(n_{2}=96\right)$, odds ratios, confidence intervals and $p$-values of independent variables)

\begin{tabular}{|c|c|c|c|c|c|c|}
\hline \multirow[t]{2}{*}{ Variables } & \multirow{2}{*}{$\begin{array}{l}\text { Total } \\
\text { number } \\
(N= \\
626)\end{array}$} & \multicolumn{2}{|c|}{$\begin{array}{l}\text { Reported bat contact } \\
(n=96)\end{array}$} & \multirow[t]{2}{*}{$\begin{array}{l}\text { Unadjusted } \\
\text { odds ratio }\end{array}$} & \multirow[t]{2}{*}{$95 \% \mathrm{Cl}$} & \multirow[t]{2}{*}{$P$-value } \\
\hline & & $n$ & $\%$ & & & \\
\hline \multicolumn{7}{|l|}{ Sociodemographic information } \\
\hline \multicolumn{7}{|l|}{ 1. Sex } \\
\hline Male & 341 & 68 & 70.83 & 2.29 & \multirow[t]{2}{*}{$1.43-3.67$} & \multirow[t]{2}{*}{$<0.001^{*}$} \\
\hline Female & 285 & 28 & 29.17 & 1 & & \\
\hline \multicolumn{7}{|l|}{ 2. Age group } \\
\hline$>36$ years & 132 & 16 & 16.67 & 0.71 & \multirow[t]{2}{*}{$0.40-1.27$} & \multirow[t]{2}{*}{0.249} \\
\hline$\leq 36$ years & 494 & 80 & 83.37 & 1 & & \\
\hline \multicolumn{7}{|l|}{ 3. Occupation } \\
\hline Agriculture-related occupation & 224 & 38 & 39.58 & 1.21 & \multirow[t]{2}{*}{$0.78-1.89$} & \multirow[t]{2}{*}{0.399} \\
\hline Other & 402 & 58 & 60.42 & 1 & & \\
\hline \multicolumn{7}{|l|}{ 4. Marital status } \\
\hline Married or cohabiting & 526 & 82 & 85.42 & 1.13 & \multirow[t]{2}{*}{$0.62-2.09$} & \multirow[t]{2}{*}{0.686} \\
\hline Single & 100 & 14 & 14.58 & 1 & & \\
\hline \multicolumn{7}{|l|}{ 5. Family size } \\
\hline$\leq 2$ people & 123 & 23 & 23.96 & 1.36 & \multirow[t]{2}{*}{$0.81-2.27$} & 0.248 \\
\hline$>2$ people & 503 & 73 & 76.04 & 1 & & \\
\hline 6. Number of children & & & & & & \\
\hline 0 children & 195 & 29 & 30.21 & 0.95 & $0.59-1.52$ & 0.829 \\
\hline$\geq 1$ children & 431 & 67 & 69.79 & 1 & & \\
\hline 7. Educational attainment & & & & & & \\
\hline$\leq$ Secondary school & 411 & 76 & 79.17 & 2.24 & $1.31-3.73$ & $0.002^{*}$ \\
\hline Other & 215 & 20 & 20.83 & 1 & & \\
\hline 8. Family monthly income & & & & & & \\
\hline$\leq 15,000$ Baht & 438 & 64 & 66.67 & 0.83 & $0.53-1.33$ & 0.443 \\
\hline$>15,000$ Baht & 188 & 32 & 33.33 & 1 & & \\
\hline 9. Own a car & & & & & & \\
\hline Yes & 314 & 41 & 42.71 & 0.70 & $0.45-1.09$ & $0.113^{*}$ \\
\hline No & 312 & 55 & 57.29 & 1 & & \\
\hline 10. Own a motorcycle & & & & & & \\
\hline Yes & 574 & 93 & 96.87 & 3.16 & $0.96-10.35$ & $0.046^{*}$ \\
\hline No & 52 & 3 & 3.13 & 1 & & \\
\hline Knowledge, attitudes, practices a & & & & & & \\
\hline 11. Human can get diseases fron & & & & & & \\
\hline True & 40 & 5 & 5.21 & 0.78 & 0.29 to 2.07 & 0.607 \\
\hline False & 586 & 91 & 94.79 & 1 & & \\
\hline 12. There are no concerns about & ases from & & & & & \\
\hline True & 48 & 8 & 8.33 & 1.11 & 0.50 to 2.55 & 0.790 \\
\hline False & 578 & 88 & 91.67 & 1 & & \\
\hline 13. Bats can transmit diseases to & & & & & & \\
\hline True & 84 & 10 & 10.42 & 0.72 & 0.36 to 1.44 & 0.348 \\
\hline False & 542 & 86 & 85.58 & & & \\
\hline 14. Bats are economically benefi & mmunity & & & & & \\
\hline Agree & 108 & 18 & 18.75 & 1.13 & 0.64 to 1.98 & 0.673 \\
\hline Disagree & 518 & 78 & 81.25 & 1 & & \\
\hline 15. One can contract diseases if & & & & & & \\
\hline True & 101 & 12 & 12.50 & 0.71 & 0.37 to 1.35 & 0.293 \\
\hline False & 525 & 84 & 87.50 & 1 & & \\
\hline
\end{tabular}


Table 5 Bivariate analysis of bat consumption behavior (Counts $\left(n_{2}=96\right)$, odds ratios, confidence intervals and $p$-values of independent variables) (Continued)

\begin{tabular}{|c|c|c|c|c|c|c|}
\hline \multirow[t]{2}{*}{ Variables } & \multirow{2}{*}{$\begin{array}{l}\text { Total } \\
\text { number } \\
(N= \\
626)\end{array}$} & \multicolumn{2}{|c|}{$\begin{array}{l}\text { Reported bat contact } \\
(n=96)\end{array}$} & \multirow[t]{2}{*}{$\begin{array}{l}\text { Unadjusted } \\
\text { odds ratio }\end{array}$} & \multirow[t]{2}{*}{$95 \% \mathrm{Cl}$} & \multirow[t]{2}{*}{$P$-value } \\
\hline & & $n$ & $\%$ & & & \\
\hline \multicolumn{7}{|c|}{ 16. One can contract diseases by drinking water from the same place as bats do } \\
\hline True & 139 & 15 & 15.63 & 0.61 & 0.34 to 1.09 & $0.092^{*}$ \\
\hline False & 487 & 81 & 84.37 & 1 & & \\
\hline \multicolumn{7}{|c|}{ 17. One can contract diseases by eating fruit left by bats } \\
\hline True & 170 & 26 & 27.08 & 0.99 & 0.61 to 1.62 & 0.986 \\
\hline False & 456 & 70 & 72.92 & 1 & & \\
\hline \multicolumn{7}{|c|}{ 18. Bat guano is safe to use } \\
\hline True & 58 & 6 & 6.25 & 0.61 & 0.26 to 1.47 & 0.268 \\
\hline False & 568 & 90 & 93.75 & & & \\
\hline \multicolumn{7}{|c|}{ 19. Bats are safe to eat } \\
\hline True & 169 & 1 & 1.04 & 0.02 & 0.00 to 0.16 & $<0.001^{*}$ \\
\hline False & 457 & 95 & 98.96 & & & \\
\hline \multicolumn{7}{|c|}{ 20. There are laws related to hunting bats for consumption } \\
\hline True & 196 & 11 & 11.46 & 0.24 & 0.13 to 0.46 & $<0.001^{*}$ \\
\hline False & 430 & 85 & 88.54 & 1 & & \\
\hline \multicolumn{7}{|c|}{ 21. Children are allowed to play with bats } \\
\hline True & 431 & 42 & 43.75 & 0.28 & 0.16 to 0.44 & $<0.001^{*}$ \\
\hline False & 195 & 54 & 56.25 & 1 & & \\
\hline \multicolumn{7}{|c|}{ 22. Found dead bats and brought home for food } \\
\hline True & 518 & 75 & 78.13 & 0.70 & 0.41 to 1.19 & 0.193 \\
\hline False & 108 & 21 & 21.87 & 1 & & \\
\hline \multicolumn{7}{|c|}{ 23. Feel safe in areas where bats live } \\
\hline True & 210 & 19 & 19.79 & 0.44 & 0.26 to 0.75 & $0.002^{*}$ \\
\hline False & 416 & 77 & 80.21 & 1 & & \\
\hline
\end{tabular}

Cut-off point for stepwise logistic regression at $p<0.15$

Table 6 Stepwise logistic regression analysis of bat consumption behavior (Coefficient, odds ratios, confidence intervals and $p$ values of independent variables)

\begin{tabular}{|c|c|c|c|c|}
\hline Variables & Coefficient & Odds ratio & $95 \% \mathrm{Cl}$ & $P$-value \\
\hline \multicolumn{5}{|l|}{ Sociodemographic information } \\
\hline Sex (male) & 0.91 & 2.48 & $1.49-4.11$ & $<0.001^{*}$ \\
\hline Educational attainment ( $\leq$ secondary school level) & 0.79 & 2.21 & $1.27-3.85$ & $0.005^{*}$ \\
\hline \multicolumn{5}{|l|}{ Knowledge, attitudes, practices and perceptions } \\
\hline Bat are safe to eat (true) & -3.36 & 0.04 & $0.01-0.254$ & $0.001^{*}$ \\
\hline There are laws related to hunting bats for consumption (agree) & -1.04 & 0.35 & $0.18-0.71$ & $0.004^{*}$ \\
\hline Children are allowed to play with bats (true) & -0.68 & 0.51 & $0.31-0.81$ & $0.006^{*}$ \\
\hline
\end{tabular}


Thailand. Our study showed that $36.42 \%$ of 626 respondents reported bat contact experiences during the past 6 months. The respondents reported finding live bats in houses, the community or tourist locations; eating bats for food; cleaning bat guano from the house or community; finding dead bats in the house; participating in bat guano mining/collecting; cleaning bat carcasses from the house or community; using bat guano as fertilizer; participating in other contact activities; and having been bitten by a bat. This current study showed an incidence of bat contact experiences $(36.42 \%)$ that was higher than that reported in a study in Canada [30], which showed that $16 \%$ of participants had direct contact with bats, and $4 \%$ found bats in their houses. However, the frequency of reports of being bitten by bats in the current study was lower $(7.02 \%)$ than that in the Canadian study (39.00\%). Interestingly, bat consumption behavior was shown in the second rank of frequent exposure behavior (42.10\%).

From the stepwise logistic regression analysis on bat contact behavior, male, low education attainment and considering bats to be economically beneficial to the community were risk factors for contact with bats. In contrast, farming or agriculture-related occupations were a protective factor against contacting bats, which was different from a study in Guatemala [31]. This might be because other occupations, e.g., temporary workers, had more chances and/or free time to hunt or purchase bats. Our results also showed inappropriate knowledge and attitudes with regard to feeling that it is safe to eat bats, allowing children to play with bats, and feeling safe in areas where bats live, which were influenced by the villagers' contact with bats. Our observations agreed with the findings from a study in Australia in which respondents had inappropriate perceptions that could lead to more bat contact/exposures [12].

The consumption of wild animals, including bats, a product often called bushmeat, poses challenges for both wildlife conservation and human health [24]. This study showed that 96 (15.34\%) of the 626 respondents reported bat consumption during the past 6 months. However, 170 respondents $(27.16 \%)$ in this study reported eating bats in their lifetime, which was higher than the studies in the Republic of Ghana (23.00\%) [22] and Madagascar (25.8\%) [23]. Thus, bat consumption incidences in Thailand should be considered a matter for concern.

This study showed that males reported more bat consumption behavior. Our findings were comparable to previous studies in which males were more likely to consume wildlife in Thailand and the Lao PDR $[10,12]$. Low education attainment was one of the risk factors that lead to bat contact and consumption. In addition, inappropriate knowledge and attitudes regarding whether it was safe to eat bats, legal to hunt bats, and safe to allow their children to play with bats could also be factors affecting bat consumption. Among the provinces, the respondents from the northern region (Chiang Mai, and Chiang Rai) reported eating bats more than those in other regions. While, the central provinces reported less bat consumption due to their beliefs and social norms per the qualitative study results. Regular law enforcement activities in the central provinces might be one of the contributing factors.

\section{Conclusions}

In conclusion, this study has provided information related to sociodemographic factors, knowledge, attitudes, perceptions, and practices that may influence bat contact and bat consumption behaviors among Thai villagers. The information from this study can be used in the development of communication interventions for zoonotic diseases related to bat contact and bat consumption behaviors in areas with similar environmental and cultural characteristics.

\section{Supplementary information}

Supplementary information accompanies this paper at https://doi.org/10. 1186/s12889-020-08968-Z.

\section{Additional file 1.}

\section{Abbreviations}

CytB: Cytochrome-b; DNP: Department of Natural Parks, Wildlife and Plant Conservation; MNRE: Ministry of Natural Resources and Environment; MOPH: Ministry of Public Health; SRS: Simple random sampling

\section{Acknowledgments}

We would like to thank Dr. Kallaya Harnpicharnchai, Mr. Vichien Patchamit, Mr. Buncha Muankla, and Mr. Suphat Hlikthuk for their support in the fields. We also thank the Chief Medical Officers of the Provincial Health Offices and their staff as well as the local authorities for their cooperation and assistance during research. We would also like to thank the Department of Natural Parks, Wildlife and Plant Conservation for their support on site and during the field bat sample collection.

\section{Authors' contributions}

KS1, PK, SK, PB, KS2, CS, and NB conducted and coordinated the field study and questionnaire interviews. KS1 and SC conducted the data analysis. KS1 and AA drafted and revised the manuscript. AA supervised the study and served as principle investigator of the project and corresponding author of the manuscript. All authors read and approved the final manuscript.

\section{Authors' information}

The first author (Kanokwan Suwannarong) is a postdoc associate at the Center of Excellence for Emerging and Re-Emerging Infectious Diseases in Animals, Faculty of Veterinary Sciences, Chulalongkorn University. She received the postdoctoral fellowship from the Second Century Fund (C2F), Chulalongkorn University. Her research interest is social epidemiology and community studies related to emerging infectious diseases and health managements.

\section{Funding}

This research was supported by the Chulalongkorn University, National Research University Fund, Health Research (NRU59-028-HR). Chulalongkorn University provided financial support to the Center of Excellence for Emerging and Re-emerging Infectious Diseases in Animals and The One Health Research Cluster. The Thailand Research Fund provided financial support to the TRF Senior Scholar to the corresponding author (RTA6080012). We would like to thank the Rachadapisek Sompote Fund and the Second 
Century Fund (C2F), Chulalongkorn University for the first author's postdoctoral fellowship as well as for study designs, data collection and analysis of this project.

\section{Availability of data and materials}

All data generated or analyzed during this study are included in this published article and supplement tables.

\section{Ethics approval and consent to participate}

The Chulalongkorn University Institution Review Boards (IRBs) and Chiang Rai provincial health office approved this human study (Ref No. 034/59 and 26/ 2559, respectively). This study obtained agreements from local administrative offices and the chiefs of villages to conduct data collection at the study sites. Written informed consent forms were obtained after describing the objectives of the study to the participants and prior to the interviews. The Faculty of Veterinary Science, Chulalongkorn University's animal care and use committee, approved the animal study (IACUC No. 1531035 and 1631006). The Department of National Park, Wildlife and Plant Conservation, Ministry of Natural Resources and Environment approved the bat sample collection (No. TS0907.4/25574)

\section{Consent for publication}

Not applicable.

\section{Competing interests}

The authors declare that they have no competing interests.

\section{Author details}

${ }^{1}$ Center of Excellence for Emerging and Re-emerging Infectious Diseases in Animals, Chulalongkorn University, Bangkok, Thailand. ${ }^{2}$ Sirinthorn College of Public Health Khon Kaen, Ministry of Public Health, Khon Kaen, Thailand. ${ }^{3}$ School of Health Science, Mae Fah Luang University, Chiang Rai, Thailand. ${ }^{4}$ Faculty of Public Health, Mahasarakham University, Mahasarakham, Thailand. ${ }^{5}$ Sirinthorn College of Public Health Trang, Ministry of Public Health, Trang, Thailand. ${ }^{6}$ The Office of Disease Prevention and Control 7 Khon Kaen, Khon Kaen, Thailand. ${ }^{7}$ Faculty of Public Health, Nakhon Sawan Campus, Mahidol University, Nakhon Sawan, Thailand. ${ }^{8}$ Faculty of Nursing, Khon Kaen University, Khon Kaen, Thailand. 'Department of Veterinary Public Health, Faculty of Veterinary Science, Chulalongkorn University, Bangkok 10330, Thailand.

Received: 17 September 2019 Accepted: 20 May 2020 Published online: 03 June 2020

\section{References}

1. Meerburg BG, Singleton GR, Kijlstra A. Rodent-borne diseases and their risks for public health. Crit Rev Microbiol. 2009;35(3):221-70. https://doi.org/10. 1080/10408410902989837.

2. Anti $P$, et al. Human-bat interactions in rural West Africa. Emerg Infect Dis. 2015;21(8):1418-21. https://doi.org/10.3201/eid2108.142015.

3. Paterson BJ, et al. Cross sectional survey of human-bat interaction in Australia: public health implications. BMC Public Health. 2014;14:58. https:// doi.org/10.1186/1471-2458-14-58.

4. Robertson K, et al. Rabies-related knowledge and practices among persons at risk of bat exposures in Thailand. PLoS Negl Trop Dis. 2011;5(6):e1054. https://doi.org/10.1371/journal.pntd.0001054

5. Wolfe ND, et al. Bushmeat hunting, deforestation, and prediction of zoonoses emergence. Emerg Infect Dis. 2005;11(12):1822-7. https://doi.org/ 10.3201/eid1112.040789.

6. Kamins $\mathrm{AO}$, et al. Characteristics and risk perceptions of Ghanaians potentially exposed to bat-borne Zoonoses through Bushmeat. Ecohealth. 2015;12(1):104-20. https://doi.org/10.1007/s10393-014-0977-0.

7. Mossoun A, et al. Bushmeat hunting and zoonotic transmission of simian Tlymphotropic virus 1 in tropical west and Central Africa. J Virol. 2017. https://doi.org/10.1128/JVI.02479-16.

8. Nielsen MR, Jacobsen JB, Thorsen BJ. Factors determining the choice of hunting and trading bushmeat in the Kilombero Valley, Tanzania. Conserv Biol. 2014;28(2):382-91. https://doi.org/10.1111/cobi.12197.

9. Suwannarong $\mathrm{K}$, et al. Hunting, food preparation, and consumption of rodents in Lao PDR. PLoS One. 2015;10(7):e0133150. https://doi.org/10.1371/ journal.pone.0133150.
10. Suwannarong K, Schuler S. Bat consumption in Thailand. Infect Ecol Epidemiol. 2016:6:29941. https://doi.org/10.3402/iee.v6.29941.

11. Muehlenbein MP. Primates on display: potential disease consequences beyond bushmeat. Am J Phys Anthropol. 2017;162(Suppl 63):32-43. https:// doi.org/10.1002/ajpa.23145

12. Suwannarong K, Chapman RS. Rodent consumption in Khon Kaen Province, Thailand. Southeast Asian J Trop Med Public Health. 2014;45(5):1209-20.

13. Luby SP, Gurley ES, Hossain MJ. Transmission of human infection with Nipah virus. Clin Infect Dis. 2009:49(11):1743-8. https://doi.org/10.1086/647951.

14. Sazzad HM, et al. Nipah virus infection outbreak with nosocomial and corpse-to-human transmission, Bangladesh. Emerg Infect Dis. 2013;19(2): 210-7. https://doi.org/10.3201/eid1902.120971.

15. Hazelton B, et al. Hendra virus: a one health tale of flying foxes, horses and humans. Future Microbiol. 2013;8(4):461-74. https://doi.org/10.2217/fmb.13. 19.

16. Leroy EM, et al. Fruit bats as reservoirs of Ebola virus. Nature. 2005; 438(7068):575-6. https://doi.org/10.1038/438575a.

17. Hanna JN, et al. Australian bat lyssavirus infection: a second human case, with a long incubation period. Med J Aust. 2000;172(12):597-9.

18. Menachery VD, et al. A SARS-like cluster of circulating bat coronaviruses shows potential for human emergence. Nat Med. 2015;21(12):1508-13. https://doi.org/10.1038/nm.3985.

19. Wacharapluesadee $S$, et al. Diversity of coronavirus in bats from eastern Thailand. Virol J. 2015;12:57. https://doi.org/10.1186/s12985-015-0289-1.

20. Wood $J$, et al. A framework for the study of zoonotic disease emergence and its drivers: spillover of bat pathogens as a case study. Philos Trans R Soc Lond Ser B Biol Sci. 2012;367(1604):2881-92. https://doi.org/10.1098/rstb. 2012.0228.

21. Bradley RD, Baker RJ. A test of the genetic species concept: cytochrome-b sequences and mammals. J Mammal. 2001;82(4):960-73.

22. Gbogbo F, Kyei MO. Knowledge, perceptions and attitude of a community living around a colony of straw-coloured fruit bats (Eidolon helvum) in Ghana after Ebola virus disease outbreak in West Africa. Zoonoses Public Health. 2017;64(8):628-35. https://doi.org/10.1111/zph.12357.

23. Jenkins RK, et al. Analysis of patterns of bushmeat consumption reveals extensive exploitation of protected species in eastern Madagascar. PLoS One. 2011:6(12):e27570. https://doi.org/10.1371/journal.pone.0027570.

24. Kamins $\mathrm{AO}$, et al. Uncovering the fruit bat bushmeat commodity chain and the true extent of fruit bat hunting in Ghana, West Africa. Biol Conserv. 2011;144(12):3000-8. https://doi.org/10.1016/j.biocon.2011.09.003.

25. JTCC AEA, Ekue BSMRM, Mensah GA. Importance of rodents as a human food source in Benin. Belg J Zool. 2005;135(supplement):11-5.

26. Cronin DT, et al. Conservation strategies for understanding and combating the primate bushmeat trade on Bioko Island, Equatorial Guinea. Am J Primatol. 2017. https://doi.org/10.1002/ajp.22663.

27. Greatorex ZF, et al. Wildlife trade and human health in Lao PDR: an assessment of the zoonotic disease risk in markets. PLoS One. 2016;11(3): e0150666. https://doi.org/10.1371/journal.pone.0150666.

28. Ordaz-Nemeth I, et al. The socio-economic drivers of bushmeat consumption during the west African Ebola crisis. PLoS Negl Trop Dis. 2017; 11(3):e0005450. https://doi.org/10.1371/journal.pntd.0005450.

29. Setalaphruk C, Price LL. Children's traditional ecological knowledge of wild food resources: a case study in a rural village in Northeast Thailand. J Ethnobiol Ethnomed. 2007;3:33. https://doi.org/10.1186/1746-4269-3-33.

30. De Serres G, et al. Bat rabies in the United States and Canada from 1950 through 2007: human cases with and without bat contact. Clin Infect Dis. 2008:46(9):1329-37. https://doi.org/10.1086/586745.

31. Moran D, et al. Knowledge, attitudes and practices regarding rabies and exposure to bats in two rural communities in Guatemala. BMC Res Notes. 2015;8:955. https://doi.org/10.1186/s13104-014-0955-1.

\section{Publisher's Note}

Springer Nature remains neutral with regard to jurisdictional claims in published maps and institutional affiliations. 